\title{
Effects of prolactin and hCG treatment on luteal activity and the conceptus during delayed implantation in Schreibers' long-fingered bat (Miniopterus schreibersii)
}

\author{
R. T. F. Bernard and C. Bojarski \\ Department of Zoology and Entomology, Rhodes University, Grahamstown 6140, South Africa
}

\begin{abstract}
In Schreibers' long-fingered bat (Miniopterus schreibersii) from South Africa, implantation is delayed from May to August during which time the corpus luteum is inactive and plasma progesterone and LH concentrations low. Treatment of pregnant long-fingered bats with exogenous prolactin for 10 days in early delayed implantation (May) resulted in changes in luteal ultrastructure that were consistent with increased steroidogenesis, high plasma progesterone concentrations and the initiation of implantation. Treatment of bats with hCG for 10 days in early delayed implantation induced similar changes in luteal ultrastructure and plasma progesterone concentrations, but did not initiate implantation. Treatment with exogenous progesterone during early delayed implantation had no influence on the corpus luteum or the conceptus. We conclude that prolactin is the most important pituitary hormone in the control of delayed implantation, although the route via which it induces implantation is unknown.
\end{abstract}

\section{Introduction}

Obligate delayed implantation occurs widely in mammals and may have evolved separately at least 17 times (Sandell, 1990). Within the Chiroptera, it is characteristic of long-fingered bats of the genus Miniopterus from temperate latitudes (for review, see Racey, 1982) and has been reported in one horseshoe bat (Rhinolophus rouxi; Ramakrishna and Rao, 1977) and the megachiropteran fruit bat (Eidolon heloum; Mutere, 1967). In Schreibers' long-fingered bat from South Africa, fertilization occurs during late April and early May and is followed by a three-and-a-half month period of delayed implantation. Implantation occurs in August and parturition in December (Bemard et al., 1991).

In most mammals that use delayed implantation, the steroidogenic activity of the corpus luteum is suppressed and plasma progesterone concentrations are low during the delay (skunk: Sinha and Mead, 1975; roe deer: Sempéré, 1977; badger: Bonnin et al., 1978; mink: Martinet et al., 1981; Sundqvist et al., 1989; and long-fingered bat: Peyre and Herlant, 1963a, b; Kimura et al., 1987; Crichton et al., 1989; Bernard et al., 1991). Typically, implantation coincides with activation of the corpus luteum and increasing plasma progesterone concentrations (Mead and Eik-Nes, 1969; Moller, 1973; Canivenc and Bonnin, 1981; Stoufflet et al., 1989).

Recent studies using mustelid carnivores have shown that prolactin is the pituitary hormone responsible for activating the corpus luteum and terminating delayed implantation, and that LH and progesterone play little or no role (Papke et al., 1980;

Received 15 February 1993
Martinet et al., 1981; Berria et al., 1989). Furthermore, the production of prolactin (and consequently luteal activation and implantation) is stimulated by increasing daylength and blocked under short day conditions or by exogenous melatonin (Mead, 1981; Martinet et al., 1983; Murphy et al., 1990). Similar data are not available for long-fingered bats, although there is some histological evidence that luteal inactivity during delayed implantation may be due to insufficient secretion by the pituitary (Peyre and Herlant, 1963b), and there is indirect evidence that increasing daylength may stimulate implantation (Racey, 1982). In view of this, the aims of the present study were to examine the roles of prolactin, hCG and progesterone in the control of luteal activity and the termination of delayed implantation in Schreibers' long-fingered bat.

\section{Materials and Methods}

\section{Animals}

Pregnant Schreibers' long-fingered bats (Miniopterus schreibersii) were collected from a series of disused mine tunnels in the East Cape region of South Africa $\left(33^{\circ} 58^{\prime} \mathrm{S}\right.$, $\left.25^{\circ} 17^{\prime} \mathrm{E}\right)$ one day before the start of each experiment. Throughout the experiments, animals were maintained in an outside flight cage and were exposed to the natural photoperiod. Two artificial roost boxes (Hill and Smith, 1985) were suspended in the flight cage and the bats used these during the daytime. Bats were fed each afternoon, by hand, on the larvae of mealworms, and given water ad libitum. Bats were weighed each afternoon after feeding and while all lost 

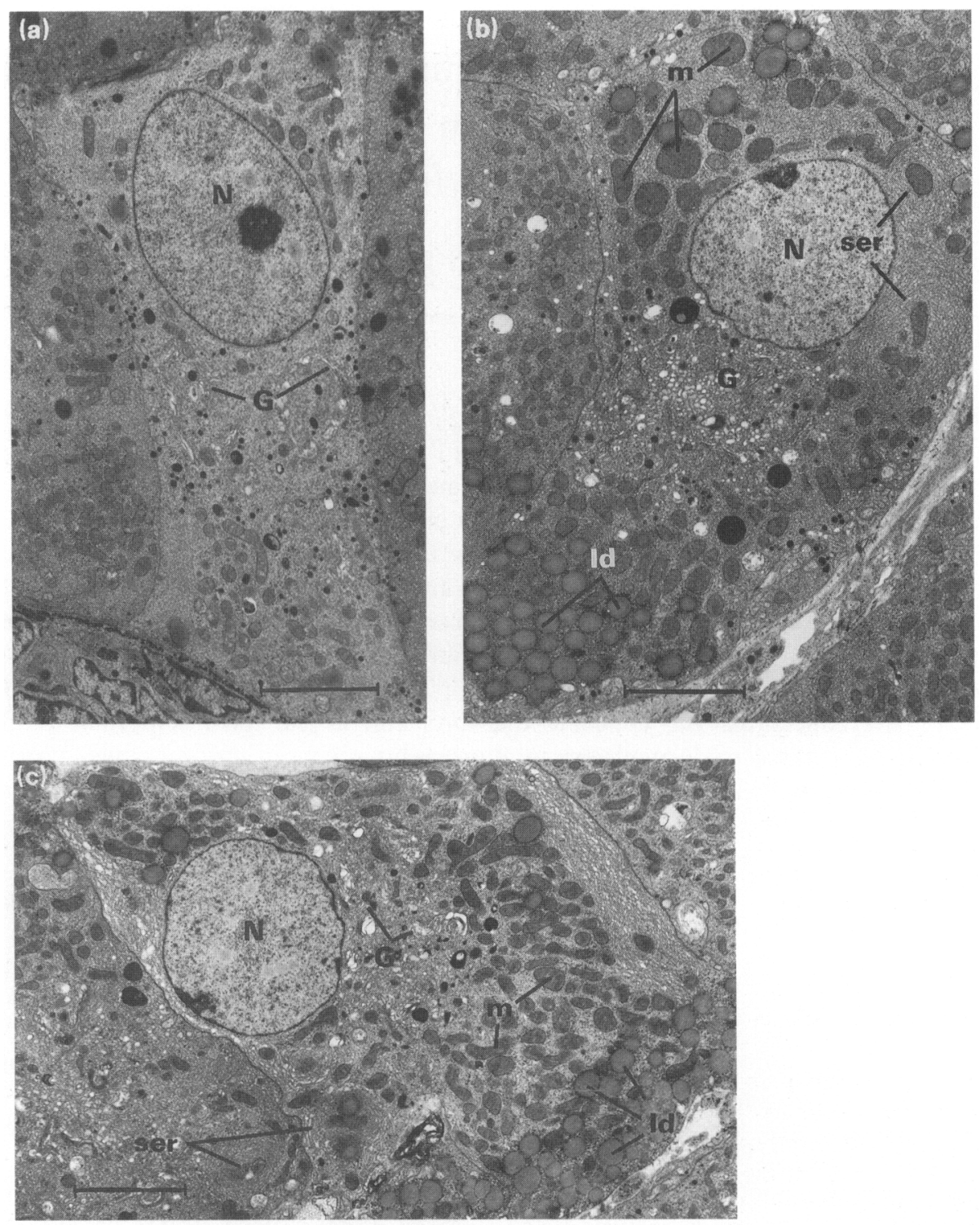

Fig. 1. Electron micrographs of luteal cells from (a) a control long-fingered bat and experimental bats that received (b) prolactin and (c) hCG. They show the accumulation of lipid droplets (Id), the very large mitochondria $(\mathrm{m})$ adjacent to the nucleus $(\mathrm{N})$ and the whorls of smooth endoplasmic reticulum (ser) that are characteristic of specimens that received prolactin or hCG. The division of the luteal cell into lipid droplet, Golgi and nuclear zones is particularly apparent in (b). G: golgi bodies. Scale bars represent $4.0 \mu \mathrm{m}$.

weight initially, most returned to or exceeded their starting weight after three days.

\section{Experimental protocol}

The first experiment was designed to test the effect of prolactin on luteal ultrastructure, plasma progesterone concentration and delayed implantation. Thirty bats were collected on 6 May 1991 of which ten received $0.01 \mathrm{mg}$ ovine prolactin (Sigma Chemical Co., St Louis, MO) in $0.1 \mathrm{ml}$ saline day ${ }^{-1}$ for 10 days, ten received $0.1 \mathrm{ml}$ of saline day ${ }^{-1}$, and ten served as untreated controls. All injections were given s.c. between the shoulder blades of the bats. Bats were anaesthetized with $0.05 \mathrm{mg}$ Nembutal $\mathrm{g}^{-1}$ body weight (Abbott, Johannesburg) $12 \mathrm{~h}$ after final treatment and were exsanguinated via the ventricles.

The left ovary (containing the corpus luteum) and right uterine horn (in which implantation occurs) of five individuals from each of the three groups were then fixed by perfusion for $10 \mathrm{~min}$, followed by immersion fixation for $4 \mathrm{~h}$ in $2.5 \%$ glutaraldehyde in phosphate buffer $\left(0.1 \mathrm{~mol} \mathrm{l}^{-1} ; \mathrm{pH} \mathrm{7.3)}\right.$. The tissues were then prepared for transmission electron microscopy using standard techniques (Bernard et al., 1991). The 
Table 1. The relative volume densities of lipid droplets, mitochondria, Golgi bodies, smooth endoplasmic reticulum (SER), and rough endoplasmic reticulum (RER) in the luteal cells of control bats and those that received $0.01 \mathrm{mg}$ prolactin day $^{-1}$ for 10 days or 1.0 iu hCG day ${ }^{-1}$ for 10 days

\begin{tabular}{lccc}
\hline Organelies & Control & Prolactin & hCG \\
\hline Lipid droplet zone & & & \\
Lipid droplets & $27.5 \pm 6.0$ & $44.5 \pm 5.7^{*}$ & $45.4 \pm 7.2^{*}$ \\
Mitochondria & $13.0 \pm 6.2$ & $12.5 \pm 4.2$ & $14.7 \pm 2.9$ \\
Golgi bodies & 0 & 0 & 0 \\
SER & $27.3 \pm 13.7$ & $28.0 \pm 5.6$ & $25.7 \pm 6.1$ \\
RER & $0.2 \pm 0.1$ & $0.9 \pm 0.7$ & $4.4 \pm 2.6^{*}$ \\
Golgi body zone & & & \\
Lipid droplets & $4.0 \pm 4.8$ & $3.3 \pm 0.3$ & $4.4 \pm 3.9$ \\
Mitochondria & $11.3 \pm 2.9$ & $9.7 \pm 6.2$ & $21.7 \pm 5.2^{*}$ \\
Golgi bodies & $15.0 \pm 2.7$ & $24.3 \pm 7.1^{*}$ & $20.3 \pm 4.9^{*}$ \\
SER & $45.7 \pm 9.4$ & $35.3 \pm 16.5$ & $41.3 \pm 5.3$ \\
RER & 0 & 0 & 0 \\
& & & \\
Nuclear zone & & $4.5 \pm 0.6$ & $3.1 \pm 1.7$ \\
Lipid droplets & $4.5 \pm 2.5$ & & \\
Mitochondria & $26.0 \pm 6.7$ & $35.8 \pm 2.9^{*}$ & $37.2 \pm 3.3^{*}$ \\
Golgi bodies & $0.3 \pm 0.5$ & $0.8 \pm 1.5$ & $0.3 \pm 1.4$ \\
SER & $45.1 \pm 1.5$ & $34.5 \pm 9.5$ & $40.6 \pm 7.8$ \\
RER & $1.0 \pm 2.0$ & $2.1 \pm 3.0$ & $3.7 \pm 2.9^{*}$ \\
& & &
\end{tabular}

Values are means $\pm \mathrm{SD}$. *Significant difference in the abundance of organelles between control and experimental bats $(P<0.05)$.

left ovary and right uterine horn from the remaining specimens were removed and prepared for standard light microscopy (Bernard et al., 1991).

The second experiment was designed to establish the role of hCG in activating the corpus luteum and terminating delayed implantation, to establish whether progesterone terminated delayed implantation, and to confirm the results of the first experiment. Forty bats were collected on 4 May 1992, of which eight received $0.4 \mathrm{mg}$ progesterone (Sigma Chemical Co.) in $0.1 \mathrm{ml}$ olive oil day ${ }^{-1}$ for 10 days, eight received $0.1 \mathrm{ml}$ of olive oil day ${ }^{-1}$, eight received 1.0 iu hCG (Pregnyl: Donmed Pharmaceuticals, Johannesburg) in $0.1 \mathrm{ml}$ saline day $^{-1}$, eight received $0.01 \mathrm{mg}$ prolactin day ${ }^{-1}$ as before, and eight served as untreated controls. Saline controls were omitted from the second experiment because previously no significant difference had been detected in luteal ultrastructure, plasma progesterone concentrations or development of the embryo between the saline controls and the untreated controls. Bats were anaesthetized $12 \mathrm{~h}$ after the final treatment as before, exsanguinated, and fixed by perfusion with $2.5 \%$ glutaraldehyde. In all cases, the left ovary was prepared for transmission electron microscopy. The right uterine horn of half of the individuals of each group was prepared for transmission electron microscopy and that of the other half for light microscopy.

Although only adult bats were used in these experiments it was impossible to establish whether mating had occurred and inevitably a few bats were found to be not pregnant after completion of the experiment. The final sample sizes were: in
1991, experimental + prolactin eight, saline control seven, untreated control eight; and in 1992, experimental + prolactin five, experimental + progesterone six, olive oil control seven, experimental + hCG seven, untreated control five.

\section{Progesterone assay}

Blood was centrifuged at $1600 \mathrm{~g}$ for $5 \mathrm{~min}$ and plasma was stored at $-20^{\circ} \mathrm{C}$ until assayed. Progesterone was measured using a standard competitive radioimmunoassay as described by Bernard et al. (1991). Crossreactivities of the progesterone antiserum were 11ß-hydroxyprogesterone $(53 \%)$, $11 \alpha-$ hydroxyprogesterone $(25 \%), 5$ pregnane-3-20-one $(22 \%)$, $17 \beta$-hydroxyprogesterone $(3 \%)$, pregnenolone $(2 \%)$, 11 deoxycorticosterone ( $2 \%)$, 11-deoxycortisol ( $2 \%$ ), 20-hydroxy4-pregnane-3-one $(0.4 \%), \quad 3$-hydroxy-5-pregnane-20-one $(0.3 \%)$, cortisol $(<0.1 \%)$, testosterone $(<0.001 \%), \Delta-4$ androstenedione $(<0.001 \%)$, oestradiol $(<0.001 \%)$ and oestrone $(<0.001 \%)$. Sensitivity was $0.31 \mathrm{ng} \mathrm{ml} \mathrm{m}^{-1}$. The intra- and interassay coefficients of variation were $<10 \%$.

Attempts to measure plasma prolactin concentrations were unsuccessful and although three different antibodies were used in the radioimmunoassay, none detected the bat prolactin.

\section{Quantitation}

All measurements were made using a digitizer tablet and SigmaScan software (Jandel Scientific, Corte Madera). The volume densities of luteal mitochondria, lipid droplets, Golgi bodies, smooth endoplasmic reticulum and rough endoplasmic reticulum were calculated using the point count method of Weibel and Bolender (1973). A grid containing 99 squares, each $9 \mathrm{~mm}^{2}$, was drawn on the screen of the electron microscope, onto which the image of the tissue was superimposed. Thirty luteal cells, chosen at random from each specimen, were selected at low power $(\times 4200)$ and the area of cytoplasm that appeared after the magnification had been increased to $\times 19000$ was used for the calculations of volume density (Crichton et al., 1989). Volume density does not take into account changes in the size of luteal cells and to obtain a value that is relative to cytoplasmic volume relative volume densities were calculated (Crichton et al., 1989). Cell size was calculated from longitudinal sections through the long axis of the luteal cells and was a simple multiplication of greatest length by greatest breadth.

\section{Statistical analyses}

Differences between means were evaluated using Student's $t$ tests, where two means are compared and one-way analyses of variance with the Tukey multiple range test where more than two means are compared. Data are presented as means \pm SD.

\section{Results}

\section{The influence of prolactin}

Daily administration of $0.01 \mathrm{mg}$ prolactin for 10 days in May 1991 and 1992 induced a modification to the luteal 

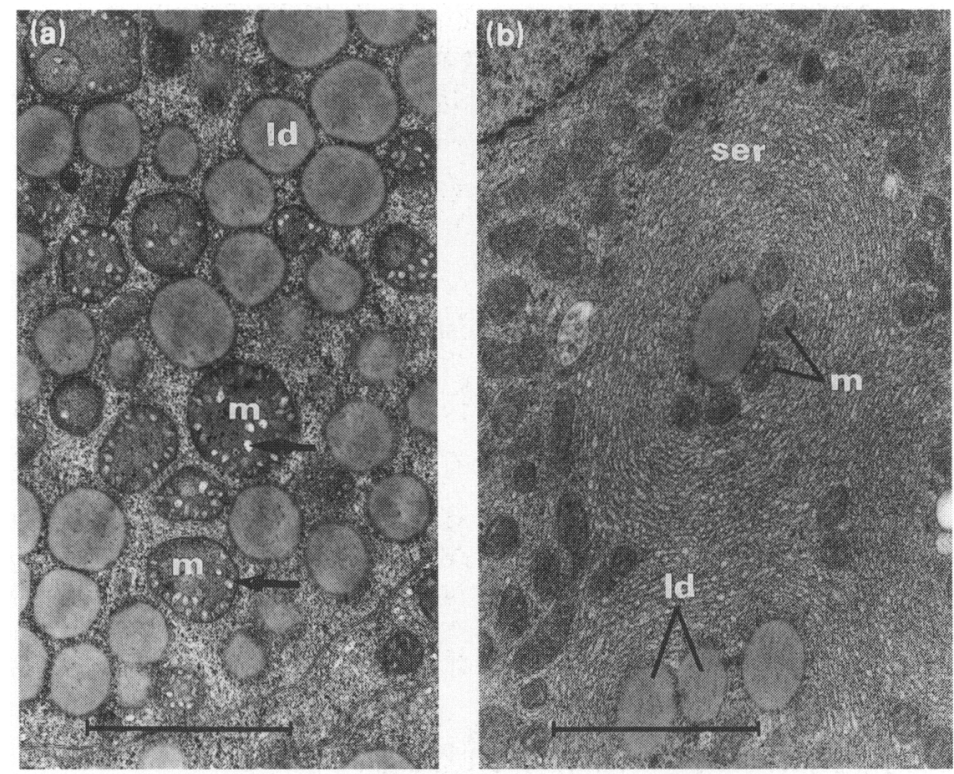

Fig. 2. Electron micrographs showing (a) mitochondria ( $m$ ) with tubular cristae (arrows) and (b) the wrapping of smooth endoplasmic reticulum (ser) in whorls around lipid droplets (ld) and mitochondria $(\mathrm{m})$ that characterizes luteal cells from long-fingered bats that have received prolactin. Scale bars represent $2.0 \mu \mathrm{m}$.

ultrastructure, a significant increase in plasma progesterone concentration, and the precocious initiation of implantation. Three bats did not respond to this treatment: luteal ultrastructure was unchanged, plasma progesterone concentrations low, and implantation was not initiated. These specimens were omitted from the analyses.

The luteal cells of the long-fingered bat can be readily divided into three zones based on the distribution of organelles (Fig. 1). The nucleus is located at one end and is surrounded by smooth endoplasmic reticulum, numerous mitochondria and some lipid droplets. At the opposite end is the lipid droplet zone, which is characterized by a variable number of lipid droplets, a few mitochondria and some rough endoplasmic reticulum. Separating these zones is the Golgi zone comprising Golgi bodies, smooth endoplasmic reticulum, some electrondense bodies and a few lysosomes (Fig. 1). Because the distribution of organelles is not random, the analysis of organelle abundance in control and experimental animals is based on 30 fields from each of the three zones of each specimen.

There was no significant difference between luteal ultrastructure or plasma progesterone concentrations of the controls that received saline and the untreated controls, or between the untreated controls of the 1991 and 1992 experiments $(P>0.05$ in all cases); for the present analysis, the three groups have been combined. Similarly, there was no significant difference between luteal ultrastructure or plasma progesterone concentrations of the bats that received prolactin in 1991 and 1992, and the two data sets were combined.

Exogenous prolactin resulted in a significant increase in cell size (control, $241 \pm 26.3 \mu \mathrm{m}^{2}$ versus experimental, $\left.291 \pm 41.3 \mu \mathrm{m}^{2} ; P<0.05\right)$. The relative volume densities of lipid droplets, Golgi bodies and mitochondria were significantly greater in the bats that received prolactin than in the controls $(P<0.05$; Table 1; Fig. 1a, b). The increase in the relative volume density of mitochondria was principally due to the appearance of very large mitochondria (mean diameter, $1.30 \pm 0.21 \mu \mathrm{m}$ ) in the nuclear zone (Fig. 1b). Mitochondria with both tubular and lamellar cristae occurred in luteal cells of both control and experimental animals (Fig. 2a), although tubular cristae were rare in the controls. In specimens that received prolactin, the smooth endoplasmic reticulum was arranged in whorls around mitochondria and lipid droplets (Figs $\mathrm{Ib}$ and $2 \mathrm{~b}$ ), an arrangement that was never observed in the luteal cells of control animals.

Plasma progesterone concentrations of the bats that received prolactin were variable $\left(1.6-16.4 \mathrm{ng} \mathrm{ml}^{-1}\right)$ but significantly higher $\left(6.2 \pm 4.9 \mathrm{ng} \mathrm{ml}^{-1}\right)$ than in the controls $(2.2 \pm 0.7 \mathrm{ng}$ $\mathrm{ml}^{-1} ; P<0.01$ ), which in turn were not significantly different from previously established concentrations for early delayed implantation (1.7 $\pm 0.6 \mathrm{ng} \mathrm{ml}^{-1} ; P>0.05$; Bernard et al., 1991).

The single zona-free embryo from control animals was always at the unimplanted bilaminar blastocyst stage with regions of the trophoblast in contact with the intact uterine epithelium (Fig. 3a). However, in the ten animals that received exogenous prolactin, the embryo was further developed and implantation was occurring (Fig. $3 \mathrm{~b}, \mathrm{c}$ ). In places the uterine epithelium had degenerated and the syncytiotrophoblast was in the process of proliferation and invading the maternal tissue (Fig. 3c). The number of endometrial glands was reduced and the endometrium appeared stratified (Fig. $3 b$ ). In four of these animals, embryonic development had progressed further and the primitive amnion had degenerated and the embryonic plate was flattened. Although both plasma progesterone 

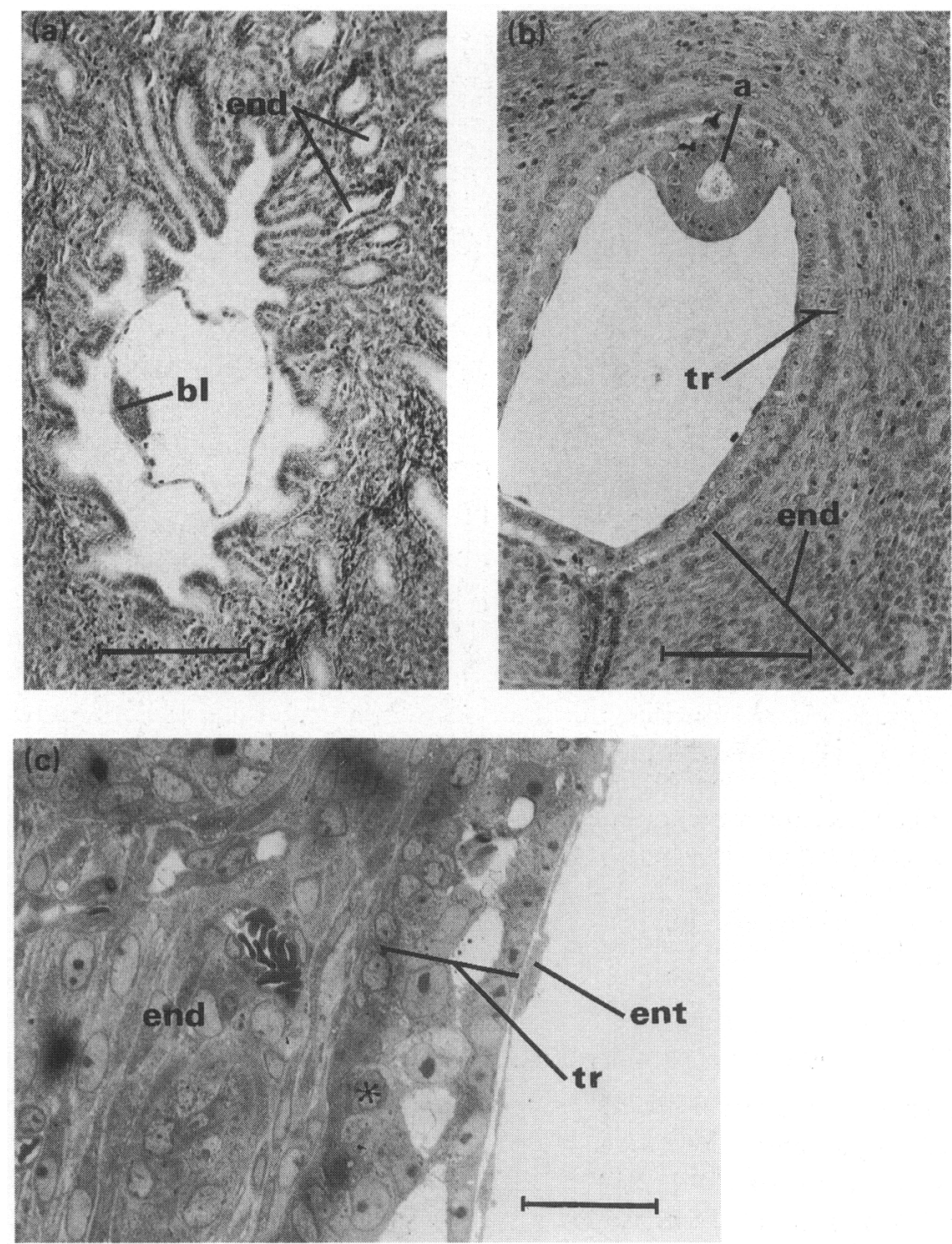

Fig. 3. (a) Light micrograph of a section through an unimplanted bilaminar blastocyst (bl) from a control long-fingered bat in early delayed implantation showing the typically glandular endometrium (end). (b) Light micrograph of a section through an implanting blastocyst from a specimen that received prolactin. Note that the trophoblast (tr) is more than one cell thick, the primitive amnion (a) is intact, that there has been a reduction in the number of uterine glands, and that the endometrium (end) appears stratified. (c) Light micrograph of a thick section through the right uterine hom of a specimen that received prolactin, showing greater detail of the multicellular trophoblast (tr) and the degeneration of the uterine epithelium $\left(^{*}\right)$ (ent: entoderm). Scale bars: (a), $0.3 \mathrm{~mm}$; (b), $0.2 \mathrm{~mm}$; (c), $0.05 \mathrm{~mm}$.

concentrations and the stage of implantation varied among the bats that had received prolactin, there was no correlation between progesterone concentration and stage of implantation.

\section{The influence of $h C G$}

Treatment with exogenous hCG for 10 days resulted in modification to the luteal ultrastructure, high plasma progesterone concentrations but no change to the conceptus.

The luteal cells of specimens treated with hCG were significantly larger $\left(282 \pm 30.8 \mu \mathrm{m}^{2}\right)$ than those of the controls $\left(228 \pm 16.4 \mu \mathrm{m}^{2} ; P<0.05\right)$ and were very similar in ultrastructure to the luteal cells of specimens treated with prolactin (compare Fig. $1 \mathrm{~b}$ and $\mathrm{c}$ ). The relative volume densities of lipid droplets, mitochondria, Golgi bodies and rough endoplasmic reticulum were significantly greater in the specimens that had received hCG than in the controls $(P<0.05$ in all cases; Table 1). Plasma concentrations of progesterone in plasma were significantly higher in bats that received hCG $(40.4 \pm 15.7 \mathrm{ng}$ $\left.\mathrm{ml}^{-1}\right)$ than in the controls $\left(2.2 \pm 0.7 \mathrm{ng} \mathrm{ml}^{-1} ; P<0.01\right)$.

In all specimens, treatment with hCG failed to activate the conceptus, which remained at the unimplanted bilaminar blastocyst stage.

\section{The influence of progesterone}

Treatment with progesterone for 10 days resulted, as expected, in a significantly higher plasma progesterone concentration $\left(132 \pm 105 \mathrm{ng} \mathrm{ml}^{-1}\right)$ than in the controls $(3.7 \pm 1.3 \mathrm{ng}$ $\left.\mathrm{ml}^{-1} ; P<0.001\right)$. However, neither progesterone nor the 
vehicle initiated implantation and in all specimens, the conceptus was at the unimplanted bilaminar blastocyst stage.

Concentrations of progesterone in plasma varied significantly between the three treatments $(P<0.001)$. Treatment with progesterone resulted in the highest plasma progesterone concentrations, while treatment with hCG resulted in a significantly higher plasma progesterone concentration than did treatment with prolactin.

\section{Discussion}

The changes in luteal ultrastructure that were induced by treating Schreibers' long-fingered bats with prolactin for 10 days in early delayed implantation are consistent with increased steroidogenic activity (Crombie et al., 1971; Hall, 1984; Hoyer et al., 1988), and this is supported by the small but significant increase in plasma progesterone concentration. Similar changes in luteal ultrastructure occur normally in the long-fingered bat at the time of implantation (Bernard et al., 1991), in the same species from Australia and the Japanese long-fingered bat (Miniopterus schreibersii fuliginosus) at the time of arousal from hibernation (Kimura and Uchida, 1983; Crichton et al., 1989), and in the Japanese long-fingered bat after artificial activation of the corpus luteum (Uchida et al., 1984).

The variation in plasma progesterone concentrations among the bats that received prolactin suggests that the individuals responded differently to the luteotrophic effects of prolactin, although this was not apparent in the analysis of luteal ultrastructure. The most dramatic influence of prolactin was the precocious induction of implantation where, after treatment for 10 days in early May (when endogenous LH concentrations are low, Bernard et al., 1991), implantation was initiated and the development stage of the conceptus was similar to that seen in the field in August. Three bats failed to respond to exogenous prolactin and this may have been caused by them developing antibodies to ovine prolactin, as has been suggested for the skunk (Berria et al., 1989).

Although endogenous plasma $\mathrm{LH}$ concentrations in the long-fingered bat are low during early delayed implantation, they are significantly higher in July, six weeks before normal implantation occurs (Bernard et al., 1991). Furthermore, plasma $\mathrm{LH}$ concentrations at implantation (August) are not significantly different from those in July, suggesting that LH may not be important in terminating delayed implantation (Bernard et al., 1991). This interpretation is supported by results from the present study, which showed that implantation was not induced in bats treated with hCG. It is possible that hCG may not be an appropriate analogue of endogenous $\mathrm{LH}$; however, hCG is clearly biologically active in the long-fingered bat, being a more potent luteotrophic agent in early delayed implantation than is prolactin. These results are consistent with published data for some of the mustelid carnivores that exhibit delayed implantation, in which exogenous prolactin activates the corpus luteum, increases concentrations of progesterone in plasma and terminates delayed implantation, whereas LH plays little or no role (Murphy, 1979; Martinet et al., 1981; Murphy et al., 1981; Berria et al., 1989). Since endogenous LH concentrations are high throughout postimplantation development, it is possible that LH plays a role in luteal maintenance at this time.

There is ample evidence that progesterone alone is not responsible for the termination of delayed implantation (Aitken, 1981; Daniel, 1981; Mead, 1981; Mead et al., 1981; Berria et al., 1989), and the results from the present study are consistent with this hypothesis. Although treatment with hCG induced an increase in plasma progesterone concentration to that typical of late pregnancy, and treatment with exogenous progesterone increased concentrations of progesterone in plasma to twice the maximum normal plasma progesterone concentration during pregnancy (Bernard et al., 1991), neither treatment induced implantation. Furthermore, there was no correlation between plasma progesterone concentration and stage of implantation in the bats that received prolactin.

In all long-fingered bats that exhibit delayed implantation, irrespective of latitude, implantation occurs as daylength increases, suggesting that increasing daylength may be the environmental cue that triggers implantation (for review, see Racey, 1982). Furthermore, in many mammals seasonal changes in daylength are mirrored by seasonal changes in plasma prolactin concentrations (roe deer: Schams and Barth, 1982; mink: Martinet et al., 1983; badger: Maurel et al., 1989; skunk: Kaplan et al., 1991). Although we have been unable to measure plasma prolactin concentrations in Schreibers' long-fingered bat, pituitary prolactin immunoreactivity is low and often undetectable during delayed implantation, and increases significantly at implantation (R.T.F. Bernard and C. Bojarski, unpublished). Taking these facts into account, and considering that exogenous prolactin induces precocious implantation in the long-fingered bat, it seems reasonable to suggest that increasing daylength is the environmental cue that triggers implantation and that this is mediated via prolactin. Although exogenous prolactin induces high plasma progesterone concentrations and implantation, the initiation of implantation is not due to progesterone alone, and the route via which prolactin induces implantation remains unknown.

The authors thank Rhodes University and the FRD for financial support, and R. Millar and D. Gray for assistance with the progesterone assay.

\section{References}

Aitken RJ (1981) Aspects of delayed implantation in the roe deer (Capreolus capreolus) Journal of Reproduction and Fertility Supplement 29 83-95

Bernard RTF, Bojarski C and Millar RP (1991) Plasma progesterone and luteinizing hormone concentrations and the role of the corpus luteum and LH gonadotrophs in the control of delayed implantation in Schreibers' long-fingered bat (Miniopterus schreibersii) Journal of Reproduction and Fertility $9331-42$

Berria M, Joseph MM and Mead RA (1989) Role of prolactin and luteinizing hormone in regulating timing of implantation in the spotted skunk Biology of Reproduction 40 232-238

Bonnin M, Canivenc R and Ribes CL (1978) Plasma progesterone levels during delayed implantation in the European badger (Meles meles) Journal of Reproduction and Fertility $\mathbf{5 2}$ 55-58

Canivenc $\mathbf{R}$ and Bonnin M (1981) Environmental control of delayed implantation in the European badger (Meles meles) Journal of Reproduction and Fertility Supplement $2925-33$

Crichton EG, Seamark RF and Krutzsch PH (1989) The status of the corpus luteum during pregnancy in Miniopterus schreibersii (Chiroptera: 
Vespertilionidae) with emphasis on its role in developmental delay Cell and Tissue Research 258 183-201

Crombie PR, Burton RD and Ackland N (1971) The ultrastructure of the corpus luteum of the guinea-pig Zeitschrift für Zellforschung 115 473-493

Daniel JC (1981) Delayed implantation in the northern fur seal (Callorhinus ursinus) and other pinnipeds Journal of Reproduction and Fertility Supplement $2935-50$

Hall PF (1984) Cellular organization for steroidogenesis International Review of Cytology 86 53-94

Hill JE and Smith JD (1985) Bats: A Natural History pp 132-133 British Museum, London

Hoyer PB, Kong W, Crichton EG, Bevan L and Krutzsch PH (1988) Steroidogenic capacity and ultrastructural morphology of cultured ovine luteal cells Biology of Reproduction 38 909-920

Kaplan JB, Berria M and Mead RA (1991) Prolactin levels in the westem spotted skunk: changes during pre- and periimplantation and effects of melatonin and lesions to the anterior hypothalamus Biology of Reproduction 44 991-997

Kimura K and Uchida TA (1983) Ultrastructural observations of delayed implantation in the Japanese long-fingered bat, Miniopterus schreibersii fuliginosus Joumal of Reproduction and Fertility 69 187-193

Kimura K, Takeda A and Uchida TA (1987) Changes in progesterone concentrations in the Japanese long-fingered bat, Miniopterus schreibersii fuliginosus Journal of Reproduction and Fertility 80 59-63

Martinet L, Allais C and Allain D (1981) Role of prolactin and LH in luteal function and blastocyst growth in mink (Mustela vison) Journal of Reproduction and Fertility Supplement 29 119-130

Martinet L, Allain D and Mernier M (1983) Regulation in pregnant mink (Mustela vison) of plasma progesterone and prolactin concentrations and regulation of the spring moult by daylength ration and melatonin injection Canadian Journal of Zoology 61 1959-1963

MaureI D, Contant C and Boissin J (1989) Effects of photoperiod, melatonin implants and castration on moulting and plasma thyroxine, testosterone and prolactin levels in the European badger (Meles meles) Comparative Biochemistry and Physiology 93 791-797

Mead RA (1981) Delayed implantation in mustelids with special emphasis on the spotted skunk Journal of Reproduction and Fertility Supplement 29 II-24

Mead RA and Eik-Nes KB (1969) Seasonal variation in plasma level of progesterone in western forms of spotted skunk Journal of Reproduction and Fertility Supplement 6 397-403

Mead RA, Concannon PW and McRae M (1981) Effect of progestins on implantation in the western spotted skunk Biology of Reproduction 25 128-133

Moller OM (1973) The progesterone concentrations in the peripheral plasma of the mink (Mustela vison) during pregnancy Joumal of Endocrinology 56 121-132

Murphy BD (1979) The role of prolactin in implantation and luteal maintenance in the ferret Biology of Reproduction 21 517-521
Murphy BD, Concannon PW, Travis HF and Hansel W (1981) Prolactin: The hypophyseal factor that terminates embryonic diapause in mink Biology of Reproduction 25 487-491

Murphy BD, DiGregoria GB, Douglas DA and González-Reyna A (1990) Interactions between melatonin and prolactin during gestation in the mink (Mustela vison) Journal of Reproduction and Fertility 89 423-429

Mutere FA (1967) The breeding biology of the equatorial fruit bat, Eidolon heloum, at latitudes $0^{\circ} 20^{\prime} \mathrm{N}$ Journal of Zoology 153 153-161

Papke RL, Concannon PW, Travis HF and Hansel W (1980) Control of luteal function in the mink by prolactin Journal of Animal Science 50 1102-1107

Peyre A and Herlant M (1963a) Ovo-implantation différée et correlations hypophyso-génitales chez la femelle du minioptère (Miniopterus schreibersii B) Compte rendu hébdomadaires des Séances-Acadamie des Sciences Paris D 257 $524-526$

Peyre A and Herlant M (1963b) Corrélations hypophysogénitales chez la femelle du Minioptère (Miniopterus schreibersii B) General and Comparative Endocrinology 3 726-727

Racey PA (1982) Ecology of bat reproduction. In The Ecology of Bats pp 57-104 Ed. TH Kunz. Plenum Press, New York

Ramakrishna PA and Rao KVB (1977) Reproductive adaptations in the Indian rhinolophid bat Rhinolophus rouxi (Temminck) Current Science 46 270-271

Sandell M (1990) The evolution of seasonal delayed implantation Quarterly Review of Biology 65 23-42

Schams D and Barth D (1982) Annual profile of reproductive hormones in peripheral plasma of male roe deer (Capreolus capreolus) Journal of Reproduction and Fertility 66 463-468

Sempéré A (1977) Plasma progesterone levels in the roe deer Capreolus capreolus Journal of Reproduction and Fertility 50 365-366

Sinha AA and Mead RA (1975) Ultrastructural changes in the granulosa lutein cells and progesterone levels during preimplantation, implantation, and early placentation in the western spotted skunk Cell and Tissue Research 164 179-192

Stoufflet I, Mondain-Monval M, Simon P and Martinet L (1989) Patterns of plasma progesterone, androgen and oestrogen concentrations and in vitro ovarian steroidogenesis during embryonic diapause and implantation in the mink (Mustela vison) Journal of Reproduction and Fertility 87 209-221

Sundqvist C, Amador AG and Bartke A (1989) Reproduction and fertility in the mink (Mustela vison) Journal of Reproduction and Fertility 85 413-441

Uchida TA, Inoue C and Kimura K (1984) Effects of elevated temperature on embryonic development and corpus luteum activity in the Japanese longfingered bat, Miniopterus schreibersii fuliginosus Joumal of Reproduction and Fertility 71 439-444

Weibel ER and Bolender RP (1973) Stereological techniques for electron microscopic morphometry. In Principles and Techniques for Electron Microscopy Vol 3 pp 237-296 Ed. MA Hyat. Van Nostrand-Reinhold, New York 